NBER WORKING PAPER SERIES

PREFERENTIAL TRADE AGREEMENTS AND THE WORLD TRADE SYSTEM:

A MULTILATERALIST VIEW

Pravin Krishna

Working Paper 17840

http://www.nber.org/papers/w17840

\author{
NATIONAL BUREAU OF ECONOMIC RESEARCH \\ 1050 Massachusetts Avenue \\ Cambridge, MA 02138 \\ February 2012
}

Paper prepared for the NBER - Bank of England Conference on "Globalization in an Age of Crisis: Multilateral Co-operation in the Twenty First Century", held September 14-16, 2011 at the Bank of England, London, UK. I am grateful to my discussants, Tony Venables and Ernesto Zedillo, to Richard Baldwin, Jagdish Bhagwati, Robert Feenstra, Alan Taylor and to participants at the March 2011 PreConference at the NBER for many helpful comments and to Nadia Rocha at the WTO for generously sharing the WTO's database on the "Anatomy of Preferential Trade Agreements". The views expressed herein are those of the author and do not necessarily reflect the views of the National Bureau of Economic Research.

NBER working papers are circulated for discussion and comment purposes. They have not been peerreviewed or been subject to the review by the NBER Board of Directors that accompanies official NBER publications.

(C) 2012 by Pravin Krishna. All rights reserved. Short sections of text, not to exceed two paragraphs, may be quoted without explicit permission provided that full credit, including $(\mathbb{C}$ notice, is given to the source. 
Preferential Trade Agreements and the World Trade System: A Multilateralist View Pravin Krishna

NBER Working Paper No. 17840

February 2012

JEL No. F1,F13

\begin{abstract}
$\underline{\text { ABSTRACT }}$
This paper reviews recent developments in international trade to evaluate several arguments concerning the merits of preferential trade agreements (PTAs) and their place in the world trade system. Taking a multilateralist perspective, it makes several points: First, despite the proliferation of PTAs in recent years, the actual amount of liberalization that has been achieved through PTAs is actually quite limited. Second, at least a few studies point to significant trade diversion in the context of particular PTAs and thus serve as a cautionary note against casual dismissals of trade diversion as a merely theoretical concern. Equally, adverse effects on the terms-of-trade of non-member countries have also been found in the literature. Third, while the literature has found mixed results on the question of whether tariff preferences help or hurt multilateral liberalization, the picture is different with the more elastic tools of trade policy, such as antidumping duties (ADs); the use of ADs against non-members appears to have dramatically increased while the use of ADs against partner countries within PTAs has fallen. Fourth, despite the rapid expansion of preferences in trade, intra-PTA trade shares are relatively small for most PTAs; multilateral remain relevant to most member countries of the WTO.
\end{abstract}

\author{
Pravin Krishna \\ Johns Hopkins University \\ 1740 Massachusetts Avenue, NW \\ Washington, DC 20036 \\ and NBER \\ Pravin_Krishna@jhu.edu
}




\section{Preferential Trade Agreements and the World Trade System: A Multilateralist View}

\section{Introduction}

A cornerstone of the World Trade Organization (WTO), is the principle of nondiscrimination: member countries may not discriminate against goods entering their borders based upon the country of origin. However, in an important exception to its own central prescript, the WTO, through Article XXIV of its General Agreement on Tariffs and Trade (GATT), does permit countries to enter into preferential trade agreements (PTAs) with one another. Specifically, under Article XXIV, countries may enter into preferential trade agreements by fully liberalizing "substantially" all trade between them while not raising trade barriers on outsiders. They are thereby sanctioned to form Free Trade Areas (FTAs), whose members simply eliminate barriers to internal trade while maintaining independent external trade policies or Customs Unions (CUs), whose members additionally agree on a common external tariff against imports from non-members. Additional derogations to the principle of non-discrimination include the Enabling Clause, which allows tariff preferences to be granted to developing countries (in accordance with the Generalized System of Preferences) and permits preferential trade agreements (which are not subject to the disciplines imposed by Article XXIV) among developing countries in goods trade.

Such preferential agreements are now in vogue. Indeed, the rise in preferential trade agreements between countries stands as the dominant trend in the evolution of the international trade system in the recent two decades, with hundreds of GATT/WTO-sanctioned agreements having been negotiated during this period and with nearly every member country of the WTO belonging to at least one PTA. Among the more prominent PTAs currently in existence are the North American Free Trade Agreement (NAFTA) and the European Economic Community (EEC), the MERCOSUR (the CU between the Argentine Republic, Brazil, Paraguay, and Uruguay) and the ASEAN (Association of South East Asian Nations) Free Trade Area (AFTA). 
Alongside this evolution of the world trade system towards preferential trade, there has been an intensification of interest in the academic and policy literature on the economics of trade preferences, the political and economic determinants of preferential agreements and the interplay between the bilateral and multilateral approaches to achieving freer trade. It has often been argued that the acceleration towards trade preferences reflects the deep frustration that countries felt with the "slow" pace of the multilateral process. It has also been argued by proponents that PTAs are a faster and more efficient way of achieving trade liberalization and that they should therefore be seen as a preferred path to get to the goal of multilateral free trade. On the other side, multilateralists have argued the possibility of welfare losses due to inefficiencies caused by preferences in trade, as imports may be sourced from inefficient partner countries rather than more efficient outsiders because of the lower tariffs faced by the former. ${ }^{1}$ This diversion of trade is also potentially costly to outsiders who are relatively handicapped in member country markets and may incur terms of trade losses in their exports. Multilateralists have also argued that preferential agreements are not to be seen as providing a simple monotonic path to multilateral free trade, warning that preferential agreements might create incentives within member countries against further multilateral liberalization. ${ }^{2}$

About two decades have passed since these recent debates over the virtues of

\footnotetext{
${ }^{1}$ It is sometimes asserted, as was the case at this conference, that the fact that countries choose preferential agreements is proof on the basis of "revealed preference" that the agreements must be welfare improving. While this might hold if trade agreements were decided on by welfare maximizing governments, it is decidedly incorrect in practice. Trade agreements are the outcome of intensely political processes in which powerful domestic lobbies often prevail over less powerful groups (for instance, domestic consumers) in influencing governments and moulding policy to best serve their interests. Clearly, there can be no presumption then that the resulting agreements are welfare improving, a fact that is well recognized by a large literature on the political economy of PTAs (see, for instance, Krishna (1998) and Grossman and Helpman (1995)).

${ }^{2}$ As noted by Professor Ernesto Zedillo in his conference discussion of this paper, NAFTA offered Mexican exporters an "opportunity to divert trade" away from their competitors in the US and Canadian market and having achieved this outcome, Mexico would be have been "quite happy" to see "preferential liberalization by the US stop" there (i.e., without extending to other countries in Latin America).
} 
preferential trade began. ${ }^{3}$ The collective experience of countries on both the preferential and multilateral fronts during this time has allowed for an empirically based discussion of a number of different questions on this topic. This paper reviews developments in international trade during this period and considers the findings of other researchers in an attempt to evaluate a range of analytical arguments in this area. Taking a multilateralist perspective, this paper makes several points. First, despite the proliferation of PTAs in recent years, the actual amount of liberalization that has been achieved through preferential agreements is actually quite limited. Specifically, trade flows between partner countries that receive tariff preferences are a relatively small fraction of world trade. This casts doubt on the claims concerning the efficiency of preferential agreements in achieving trade liberalization. Second, while the literature offers mixed views on whether liberalization achieved through preferential agreements has been welfare improving in practice, a few studies point to significant trade diversion in the context of particular PTAs. This should, at a minimum, serve as a cautionary note against casual dismissals of trade diversion as a merely theoretical concern. Equally, adverse effects on the terms-of-trade of non-member countries have also been found in the literature, highlighting the potential for PTAs to negatively impact outsiders. Third, while a rich empirical literature has found mixed results on the question of whether tariff preferences help or hurt multilateral liberalization, the picture is different with the more elastic tools of trade policy, such as antidumping duties (ADs); a recent study has shown that the use of ADs against non-members has dramatically increased while the use of ADs against partner countries within PTAs has fallen. Fourth, despite the rapid expansion of preferences in trade, intraPTA trade shares are relatively small for most PTAs. This suggests that multilateral initiatives involving trade with the rest of the world remain relevant to most member countries of the WTO.

\footnotetext{
${ }^{3}$ See, for instance, Bhagwati (1993) and Baldwin and Venables (1995). See also Bhagwati 2008) and Panagariya (2000) which provide comprehensive discussions of the major theoretical contributions and policy debates in this area.
} 
Finally, this paper considers the recently evolving and popular argument that the motivation for PTAs has little to do with the lowering of trade barriers, as such, and that PTAs are primarily a vehicle for undertaking "deeper" forms of integration to achieve institutional harmonization with partners. ${ }^{4}$ The institutional and policy dimensions along which this harmonization is sought include both provisions that currently fall under the mandate of the WTO and are subject to some level of commitment in WTO agreements (such as the improvement of customs administration and rules concerning public procurement) and those that currently fall outside of mandate of the WTO (such as provisions on investment measures, labor market regulations, innovations policy and human rights). To examine the argument concerning deeper integration, we use a data set recently compiled by the WTO (for its 2011 publication of the World Trade Review) which codifies these institutional provisions in more than a hundred PTAs notified to the WTO, and additionally indicates which of these provisions are legally enforceable. While it is indeed true that a number of PTAs have incorporated provisions on a range of issues that go beyond trade, the picture is again a mixed one. On the one hand, a number of provisions covered by the WTO are also mentioned in the text of these PTAs and many appear to have legally enforceable status. On the other hand, provisions that fall outside of the WTO mandates but are covered by PTAs and are also deemed legally enforceable by the text of the PTA are far fewer in number. This, in itself, permits some skepticism on how much deeper PTAs, on average, have gone beyond the possibilities offered by the WTO. Whether harmonization at the bilateral level itself is optimal and whether or not the additional provisions will have significant economic effects (for instance, on the bilateral flow of investments) remain open questions for future research.

Two final comments may be made relating to casual commentary on PTAs

The rest of the paper considers each of these arguments in turn.

\footnotetext{
${ }^{4}$ See Lawrence (1997).
} 


\section{How Much Trade Has Been Liberalized Through PTAs?}

A major argument made by the proponents of regionalism concerns the slow pace of the multilateral process in achieving trade liberalization. With this as background we may ask how much trade has actually been liberalized by preferential trade agreements and whether countries have managed to liberalize, through bilateral agreements, trade that they have been otherwise been unable to liberalize multilaterally. ${ }^{5}$

The analysis provided by the recent World Trade Report (WTR) 2011 is instructive in this regard. The WTR reports that there has been a significant increase in the value of trade taking place between PTA members. In 1990, trade between PTA partners made up around 18 percent of world trade and that this figure rose to 35 percent by 2008 (in both cases, the figures indicated exclude intra-EU trade). When the European Union is included, intra-PTA trade rose from about 28 percent in 1990 to a little over 50 percent of world trade. In dollar terms, the value of intra-PTA trade, excluding the EU countries, rose from 537 billion USD in 1990 to 4 trillion USD by 2008 and from 966 billion to nearly 8 trillion once the EU is included. This suggests that by now a large share of world trade is taking place between PTA members. However, as the WTR points out, these statistics vastly overstate the extent of preferential trade liberalization and thus the extent of preferential trade that is taking place. This is so because much of the trade between PTA members is in goods on which they impose MFN tariffs of zero in the first place. And goods which are subject to high MFN tariffs are also often subject to exemptions from liberalization under PTAs, so that the volume of trade that benefits from preferences is, on average, quite low.

\footnotetext{
${ }^{5} \mathrm{As}$ is discussed in the next section, increases in intra-PTA trade volumes, often cited as an indication of the success of a given PTA, are not necessarily welfare improving, as they may be "trade diverting" flows. Thus, increased intra-PTA trade flows which are often cited However, we set this concern aside for the present discussion.
} 
Specifically, WTR calculations indicate that despite the recent explosion in PTAs, only about 16 percent of world trade takes place on a preferential basis (the figure rises to 30 percent when intra-EU trade is included in the calculations). Furthermore, less than 2 percent of trade (4 percent when the EU is included) takes place in goods which receive a tariff preference that is greater than 10 percent. For instance, well over 50 percent of Korean imports enter with zero MFN tariffs applied to them. Korea offers preferences to about 10 percent of its imports, but a preference margin greater than 10 percent on virtually none of its imports. Similarly, in India, goods entering under preference are about five percent of overall imports with over 50 percent of imports coming in under zero MFN tariffs and virtually no imports receiving a preference of greater than 10 percent. A similar picture emerges on the exporting side. One of the countries that has actively negotiated PTAs is Chile and 95 percent of Chilean exports go to countries that it has a PTA with. However, only 27 percent of Chilean exports are eligible for preferential treatment and only 3 percent of its exports benefit from preference margins greater than 10 percent. Table I provides an additional breakdown of the volumes of trade that enter on a preferential and on an MFN basis for a number of sample PTAs. Clearly for most PTAs the majority of their trade takes place under zero MFN tariffs. It is only a small fraction of trade that enters on a preferential basis, especially outside of the EU and NAFTA.

Taken together, the preceding statistics suggest that the extent of trade liberalization undertaken through PTAs has been quite modest, despite the large number of PTAs that have in fact been negotiated. These observations challenge the claim by proponents of regionalism that preferential agreements are a faster or more efficient way of achieving trade liberalization. ${ }^{6}$ At some level this should not

\footnotetext{
${ }^{6}$ In addition, it may be noted that the discussion and negotiation over particular PTAs has sometimes also taken a significant amount of time - comparable to the duration of multilateral trade negotiation rounds at the WTO. For instance, the CAFTA-DR agreement, a free trade area between the United States and the Central American countries of Costa Rica, El Salvador, Guatemala, Honduras and Nicaragua and the Dominican Republic took well over a decade, from 1992 when it was initially
} 
perhaps be too surprising. It is widely understood that a major factor working against trade liberalization is the political opposition of the import competing lobbies. If this is the case, it is unclear why lobbies that oppose trade liberalization at the multilateral level would easily support liberalization undertaken on a preferential basis. We should therefore expect that political lobbies would mostly only permit preferential agreements in which their rents were protected, either through access to partner country markets, or , more simply, through an exemption of liberalization on imports of those goods that compete with their own production, suggesting complementarities between MFN and PTA tariffs.

To explore the question of whether MFN tariffs and PTA tariffs are indeed complements, Baldwin and Seghezza (2010) examined correlations between MFN and PTA tariffs at the 10 digit level of disaggregation for 23 of the top exporting countries within the WTO (for which data was available). Consistent with the preceding discussion, they find that MFN tariffs and PTA tariffs are complements, since the margin of preferences tends to be low or zero for products where nations apply high tariffs. This finding of complementarity has been confirmed in the more detailed studies by Joshi (2010a and 2010b) for NAFTA and the EU. All of these studies suggest that third factors, such as vested sectoral interests, drive trade policy at both the multilateral and the bilateral level. The implication is that we should not expect liberalization that is difficult at the multilateral level, to necessarily proceed easily at the bilateral level.

\section{Trade Creation and Trade Diversion}

Does preferential trade liberalization in favor of particular trading partners have the same welfare consequences as non-discriminatory trade liberalization in favor of all imports? Do a simple proportion of the welfare benefits of non-discriminatory free trade accrue with preferential liberalization? Are free trade areas to be equated 
with free trade? A thorough answer to these questions would require a deep plunge into the abstruse world of the second-best (whose existence and complexities were indeed first discovered and developed by analysts working on the economics of PTAs). But the idea may be introduced in a rudimentary fashion using the following "textbook" representation of Viner's (1950) classic analysis: Consider the case of two countries, A and B, and the rest of the world W. A is our "home" country. A produces a good and trades it for the exports of its trading partners B and W. Both B and $\mathrm{W}$ are assumed to export the same good and offer it to $\mathrm{A}$ at a fixed (but different) price. Initially, imports from $B$ and $W$ are subject to non-discriminatory trade restrictions: tariffs against $\mathrm{B}$ and $\mathrm{W}$ are equal. Imagine now that $\mathrm{A}$ eliminates its tariffs against $\mathrm{B}$ while maintaining its tariffs against $\mathrm{W}$. This is preferential tariff reduction as opposed to free trade, since the latter would require that tariffs against $\mathrm{W}$ be removed as well. It is very tempting to think that this reduction of tariffs against $B$ is a step in the direction of free trade and therefore that this ought to deliver to country A a proportionate fraction of the benefits of complete free trade. But Viner showed that this need not (and generally would not) be the case. Indeed, while a complete move towards free trade would be welfare improving for country A, Viner demonstrated that the tariff preference granted to B through the FTA could in fact worsen A's welfare.

Figures I and II illustrate preferential tariff reform as respectively welfareenhancing and welfare worsening. The y-axes denote price and the $\mathrm{x}$-axes denote quantities. $M_{A}$ denotes the import demand curve of country A. $E_{B}$ and $E_{W}$ denote the price at which countries B and W are willing to supply A's demand; they represent the export supply curves of $B$ and $W$ respectively. In Figure I, B is assumed to be a more efficient supplier of A's import than is W: $E_{B}$ is drawn below $E_{W}$, and its export price $P_{B}$ is less than W's export price $P_{W}$. Let " $T$ " denote the non-discriminatory per-unit tariff that is applied against $\mathrm{B}$ and $\mathrm{W}$. This renders the tariff-inclusive price to importers in $\mathrm{A}$ as $P_{B}+T$ and $P_{W}+T$ respectively. With this 
non-discriminatory tariff in place, imports initially equal $M_{0}$ and the good is entirely imported from B. Tariff revenues in this initial situation equal the areas $(1+2)$. When tariffs against B are eliminated preferentially, imports rise to $M_{P T}$. Imports continue to come entirely from B (since the import price from B now, $P_{B}$, is lower than the tariff-inclusive price of imports from $\mathrm{W}, P_{W}+T$ ). The tariff preferences granted to B simply increase the volume of imports. This increase in the volume of trade with the country whose exports were initially being purchased by A anyway (i.e., with the more efficient producer) when tariffs against it are preferentially reduced is referred to as "trade creation." Trade creation here can be shown to be welfare improving. The increase in benefit to consumers (consumer surplus) in A following the reduction in consumption prices from $P_{B}+T$ to $P_{B}$ equals the areas $(1+2+3+4)$. No tariff revenue is now earned and so the loss of tariff revenue equals areas $(1+2)$. The overall gain to $\mathrm{A}$ from this preferential tariff reduction equals areas $(1+2+3+4)-(1+2)=$ areas $(3+4)$, a positive number. The trade-creating tariff preference is thus welfare improving.

In demonstrating that the tariff preference we have considered is welfare improving for the home country, A, we have assumed that the partner which receives this tariff preference, B, is the more efficient supplier of the good. Figure II reverses this assumption, making $\mathrm{W}$, the rest of the world, the more efficient supplier of the good. $E_{W}$ is thus drawn below $E_{B}$. Initial imports are $M_{0}$. The tariff revenue collected is equal to the areas $(1+2)$. When tariffs are eliminated against $B$, the less efficient partner, the tariff-inclusive price of imports from $\mathrm{W}$ is higher than the tariffexclusive price from B (this need not necessarily be the case, it is simply so as drawn). This implies that all trade is now "diverted" away from $\mathrm{W}$ to $\mathrm{B}$. What is the welfare consequence of this trade diversion? The increase in consumer surplus is equal to the areas $(1+3)$ since consumers now pay a price equal to $P_{B}$ for this good. The loss in tariff revenue is $(1+2)$. The overall gain to A equals the area (3-2), which mayor may not be positive. Thus a trade diverting tariff preference may lead to a 
welfare reduction. ${ }^{7}$

The preceding discussion leaves us with three important implications. First, liberalization undertaken in a preferential context may actually result in a greater degree of trade protection (for inefficient partners). Second, measured increases in intra-PTA trade volumes do not automatically indicate an improved economic outcome. Finally, the possibility of welfare reducing liberalization clearly distinguishes preferential liberalization from multilateral liberalization.

A variety of recent contributions in the economics literature have examined the trade creating and trade diverting effects of preferential agreements. In a recent paper, Romalis (2007), investigates the effects of NAFTA and the previously formed Canada-US Free Trade Agreement (CUSFTA) on trade flows. Romalis finds that NAFTA and CUSFTA had a substantial impact on international trade volumes, but a modest effect on prices and welfare. While he finds that while NAFTA and CUSFTA increased North American output in many highly protected sectors, imports from non-member countries were driven out, suggesting trade diversionary effects. Other papers analyzing the trade effects of CUSFTA include Clausing (2001) and Trefler (2004). Using cross sectional variation in the extent of trade liberalization, both papers attempt to estimate the relative magnitudes of trade creation and trade diversion caused by CUSFTA. Both analyses find that trade creation dominated trade diversion and Trefler (2004) reports a positive welfare outcome for Canada overall.

A number of studies have used "gravity" specifications to examine the impact of preferential trade agreements on trade. Two prominent recent examples include

\footnotetext{
${ }^{7}$ The preceding examples illustrate a central issue emphasized in the academic literature on the welfare consequences of preferential trade. Preferential trade liberalization towards the country from whom the good was imported in the initial non-discriminatory situation creates more trade and increases welfare; preferential liberalization that diverts trade instead may reduce welfare. Subsequent analysis also developed examples of both welfare improving trade-diversion and welfare-decreasing trade creation in general equilibrium contexts broader than those considered by Viner. However, the intuitive appeal of the concepts of trade creation and trade diversion has ensured their continued use in the economic analysis of preferential trade agreements, especially in policy analysis (see Panagariya (2000) for a comprehensive survey).
} 
Magee (2008) and Baier and Bergstrand (2007). Using panel data from over a hundred countries going nearly two decades (1980-1998), Magee (2008) estimates trade creation and trade diversion effects of preferential trade agreements and finds this trade and welfare impact to be small, although trade creation dominates trade diversion in his analysis. Using a similar sample of countries, but going back further in time (1960-2000), Baier and Bergstrand (2007) estimate trade creation effects by considering explicitly the endogeneity of preferential trade agreements (but excluding by assumption any trade diversion effects) using the following specification. Baier and Bergstrand find the endogeneity of trade agreements to be crucial, and report that accounting for this endogeneity raises by about five times the estimate of the increase in trade flows between member countries (see Table II). Specifically, trade between member countries is predicted to double in ten years after the formation of the FTA. ${ }^{8}$

The preceding discussion covers only a small sample of the research quantifying trade creation and trade diversion effects with trade preferences. Nevertheless, it should suffice to illustrate the wide range of estimates that have been obtained. On the one hand, the findings in many papers suggest that changes in trade flows due to trade preferences will be small. On the other, hand, some papers have suggested the possibility of significant trade diversion, while others have estimated large trade creation effects. The evidence is clearly mixed.

One study that is additionally noteworthy, because of its detailed and unusual focus on changes in industry trade flows as related to patterns of comparative advantage is Yeats (1998) which investigated trade diversion within PTAs by performing an evaluation of trade patterns within MERCOSUR. Specifically, to study the impact of MERCOSUR on trade patters, Yeats (1998) characterized goods using two measures. The first measure is a "regional orientation" index (for good $i$ ) which is the ratio of the share of that good in exports to the region to its share in exports to third

\footnotetext{
${ }^{8}$ However, as we have indicated before, increases in intra-PTA trade are not necessarily welfare improving. For this to be ascertained, the extent of trade diversion has to be determined as well.
} 
countries. Specifically,

$$
R O_{i}=\frac{[(\text { Within MERCOSUR exports of good } \mathrm{i}) /(\text { Within MERCOSUR exports })]}{[(\text { MERCOSUR exports of good } \mathrm{i}) /(\text { Total MERCOSUR exports })]}
$$

The second measure is the "revealed comparative advantage" (of good $i$ ) which is the ratio of the share of good in MERCOSUR's exports to third countries to its share in world exports (exclusive of intra-MERCOSUR trade). Specifically,

$$
R C A_{i}=\frac{[(\text { MERCOSUR exports of good } \mathrm{i}) /(\text { Total MERCOSUR exports })]}{[(\text { World exports of good } \mathrm{i}) /(\text { Total World exports })]}
$$

Yeats then compares the change in goods' regional orientation index between 1988 and 1994 (before and after MERCOSUR) with their revealed comparative advantage ranking. The results of his study are striking. As he notes, the goods with the largest increase in regional orientation are goods with very low revealed comparative advantage rankings. Specifically, for the 30 groups of goods with the largest increases in regional orientation, only two had revealed comparative advantage indices above unity (see Table II). That is, the largest increases in intra-MERCOSUR trade have been in goods in which MERCOSUR countries lack comparative advantage suggesting strong trade diversionary effects. This is a striking finding and provides a cautionary note against the dismissals of trade diversion as a merely theoretical concern.

Bhagwati (2008) has discussed a variety of additional issue surrounding the question of trade diversion in practice. For instance, even though Article XXIV of the GATT prevents PTA countries from raising their tariffs against non-member countries, this restriction applies to the MFN tariff bindings agreed to by the member countries at the WTO. In practice, MFN tariffs applied by countries often lie below these bound tariffs. Thus despite the disciplines imposed by Article XXIV, PTA countries are able to raise their barriers against non-members from the applied 
level up to the bound level (thus increasing the worry of trade diversion), as was the case with Mexico following NAFTA. Furthermore, external barriers may be raised through other forms of administered protection, such as anti-dumping duties (which we discuss in greater detail in section IV.3). Finally, the extensive use of "rules of origin" in PTAs which purport to determine the origin of goods so as to determine whether they qualify for trade preferences offered by the PTA, raise protection to suppliers of intermediate goods within the PTA and may thus divert trade away from more efficient suppliers of intermediates outside.

\section{1 External Terms of Trade}

Thus far, we have focused our discussion largely on trade flows and welfare consequences of preferential trade liberalization on the countries undertaking the liberalization. While we have not explicitly considered this so far, it should be easy to see that changes in demand by PTA members for the rest of the world's exports could lower the relative price of these exports (i.e., worsens the rest of the world's terms of trade). In general, the overall effect on the external terms of trade may be seen as a combination of income and substitution effects. The former represents the effect of real income changes due to the PTA on demand for imports from nonmembers and the latter reflects the substitution in trade towards from partner countries (and away from non-member) due to the preferences in trade. In the case of a real-income reducing PTA, both effects would combine to lower demand from the rest of the world. This is also the case when substitution effects dominate the income effect. 9

Some indication of how the terms of trade may change for non-member countries in practice is provided by the empirical analysis of Chang and Winters (2002) who

\footnotetext{
${ }^{9}$ See Mundell (1964) for an analysis if how such extra-union terms of trade effects may complicate matters further for the tariff-reducing country, whose terms of trade with respect to the rest of the world may rise or fall following a preferential reduction in its tariffs against a particular partner. On this point see also the recent analysis by Panagariya (1997)
} 
examine the impact of MERCOSUR (specifically, the exemption in tariffs that Brazil provided to its MERCOSUR partners) on the terms-of-trade (export prices) of countries excluded from the agreement. Theory would suggest that trade diversion would worsen the terms of trade of excluded countries and this indeed is what they find. They report significant declines in the export prices of the Brazil's major trading partners (the United States, Japan, Germany and Korea) following MERCOSUR. (See Figure YYY). These associated welfare losses sustained by the excluded countries are significant as well - amounting to roughly ten percent of the value of their exports to Brazil. For instance, the United States is estimated to lose somewhere between 550 to 600 million dollars on exports of about 5.5 billion dollars with Germany losing between 170 and 236 million dollars on exports of about 2 billion dollars.

\section{Preferential Trade Agreements and the Multilateral Trade System}

\section{1 Expansion of Trade Blocs - Theory}

Stimulated by the theoretical results concerning the generally ambiguous welfare results associated with trade preferences, an important literature has studied the design of necessarily-welfare-improving PTAs. A classic result stated independently by Kemp (1964) and Vanek (1965) and proved subsequently by Ohyama (1972) and Kemp and Wan (1976) provides a welfare-improving solution for the case of CUs. Starting from a situation with an arbitrary structure of trade barriers, if two or more countries freeze their net external trade vector with the rest of the world through a set of common external tariffs and eliminate the barriers to internal trade (implying the formation of a $\mathrm{CU}$ ), the welfare of the union as a whole necessarily improves (weakly) and that of the rest of the world does not fall. ${ }^{10}$ The Kemp-Wan-Ohyama

\footnotetext{
10 The logic behind the Kemp-Wan theorem is as follows: By fixing the combined, net extra-union trade vector of member countries at its pre-union level, non-member countries are guaranteed their original level of welfare. Since there is no diversion of trade in this case, the welfare of the member
} 
analysis of welfare improving CUs does not automatically extend to FTAs since member-specific tariff vectors in the case of FTAs imply that domestic-prices will differ across member countries. Panagariya and Krishna (2002) has, nevertheless, recently provided a corresponding construction of necessarily welfare-improving FTAs in complete analogy with the Kemp-Wan CU. Taken together, these contributions suggest that, in principle, preferential trade agreements could expand sequentially to include the whole world, while monotonically raising welfare along the way.

But will PTAs expand successively to eventually include all trading nations? ${ }^{11}$ Will preferential liberalization prove a quicker and more efficient way of getting to global free trade than a multilateral process? ${ }^{12}$ These questions concerning the interaction between preferential trade liberalization and the multilateral trade system are important and complex in that they involve economic considerations and political factors as well. Recently, several attempts have been made in the economic literature to understand the phenomenon of preferential trade and its interaction with the multilateral trade system -- taking into account the domestic determinants (political and economic) of trade policy.

Levy (1997) has modeled trade policy as being determined by majority voting and where income distributional changes brought about by trade lead to different degrees of support (or opposition) by different members of society. He finds that bilateral agreements could preclude otherwise feasible multilateral liberalization if crucial voters (or more generally voting blocs) enjoyed a greater level of welfare under the bilateral agreement than they would under multilateral free trade.

countries is also not adversely affected. The PTA thus constructed has a common internal price vector, implying further a common external tariff for member countries. The Kemp-Wan-Ohyama design, by freezing the external trade vector and thus eliminating trade diversion, offers a way to sidestep the complexities and ambiguities inherent in the analysis of PTAs.

${ }^{11}$ See the related discussion in Bhagwati (1993) of what Bhagwati has called the "dynamic time-path question".

${ }^{12}$ This question has often been referred to in the literature as the "stumbling-bloc versus buildingbloc" question in the phrasing of Bhagwati (1993). 
Grossman and Helpman (1995) and Krishna (1998) have both modeled the influence of powerful producers in decision making over a country's entry into a PTA, and while their models and analytic frameworks differ in detail, they come to a similar and striking conclusion, that PTAs that divert trade are more likely to win internal political support. This is so because governments must respond to conflicting pressures from their exporting sectors, which gain from lower trade barriers in the partner, and their import-competing sectors, which suffer from lower trade barriers at home, when deciding on whether to form or enter a PTA. As Krishna (1998) argues, trade diversion effectively shifts the burden of the gain to member-country exporters off member-country import-competing sectors and onto non-member producers, who have little political clout inside the member countries. Krishna (1998) also argues that such PTAs will lower the incentives for any subsequent multilateral liberalization - producers in trade diverting PTAs may oppose multilateral reform since this would take away the gains from benefits of preferential access that they enjoyed in the PTA that diverted trade to them. Under some circumstances, the incentive for further multilateral liberalization is completely eliminated. Both sets of papers we have discussed above argue that bilateral agreements could impede progress towards multilateral free trade and thus undermine the multilateral trade system.

Ornelas (2005a) reconsiders the preceding analyses in a context in which the external tariffs are determined endogenously rather than historically set (as implicitly assumed by Grossman and Helpman (1995) and Krishna (1998). Through general equilibrium effects having to do with the leakage of protection to partner countries and changes in the difficulty of redistributing surplus through trade policies under an FTA, he finds, contrary to Grossman and Helpman (1995) and Krishna (1998), that it is only sufficiently welfare enhancing FTAs that are politically viable and also that predicts that external tariffs will fall subsequent to the formation of an FTA. However, in subsequent work, Ornelas (2005b) argues that when political lobbies are also allowed to lobby for the decision on the trade regime, one cannot rule out the political viability of welfare reducing FTAs. 
Baldwin (1995), on the other hand, has argued that PTA expansion could have "domino" effects - increasing the size of a bloc increases the incentive for others to join it (as they then gain preferential access to increasingly large markets). In combination with his "Juggernaut" view that initial tariff cuts will lead to increased momentum for greater trade liberalization, ${ }^{13}$ he argues that PTAs may lead towards multilateral free trade.

Yi (1996), using advances in endogenous coalition theory, ${ }^{14}$ has compared theoretical outcomes with PTAs under two regimes, "open" membership and "unanimous" membership. Under open membership rules any country interested in joining an existing PTA is able to do so while under unanimous membership, a new country may join only if all existing members agree to admit the new member. The differences in outcomes are striking. Global free trade is an equilibrium outcome with open membership rules but this generally does not obtain under unanimous membership. Intuitively, while some within union members may have reasons not to expand membership (for reasons similar to what we have discussed before), outsiders who have had trade diverted away from them will generally be tempted to join - especially as a union expands and yet greater trade is diverted away from them. While unanimous membership rules will stop the expansion of the bloc well before global free trade is reached, open membership will accelerate the movement to global free trade. While these results have been only been rigorously demonstrated in the context of the specific theoretical structure assumed by $\mathrm{Yi}$ (1996), they have strong intuitive appeal. That open membership rules will bring us closer to global free trade can also be seen to hold in a variety of different

\footnotetext{
${ }^{13}$ In this view, reciprocity within the WTO implies that initial tariff cuts create an increasing momentum for further cuts by altering the domestic political economy in favor of exporting lobbies and against import competing lobbies. See Baldwin (2004).

${ }^{14}$ See also Saggi and Yildiz $(2008,2009)$ for innovative formulations of the question of preferential agreements using the theory of endogenous coalitions and taking into account country asymmetries in equilibrium determination.
} 
formulations of the problem..$^{15,16,17}$

Thus, the theoretical literature has highlighted a variety of political and economic forces that may lead PTAs to support or oppose progress towards multilateral liberalization. Which of these forces will dominate is an empirical question and it is to empirical evaluations of these linkages that we turn to next.

\section{2 Tariff Preferences and Multilateral Liberalization -- Empirical Evidence}

The interplay between trade preferences and multilateral liberalization has been studied in a number of papers in the literature. Estevadeordal et al. (2008) has studied the effect of preferential tariffs on external trade liberalization in a group of ten Latin American countries by asking whether the MFN tariff by a country on imports of any given good (defined at the ISIC 4 Digit-level) are related to the corresponding preferential tariff applied by the country in the preceding period. They find no evidence that trade preferences in FTAs within Latin America led to higher external tariffs or smaller tariff cuts, but find instead that preferences induce a faster decline in external tariffs. ${ }^{18}$ In CUs within Latin America, however, preferential liberalization is not associated with any change in external tariffs.

\footnotetext{
${ }^{15}$ Open membership thus appears to be a valuable complement to the preferential integration process. Nevertheless, open membership in combination with preferential trade integration does not imply that discrimination is eliminated -- clearly outsiders at any point in time will still face discriminatory trade barriers. Nor does open membership guarantee a faster path to global free trade than the multilateral process. Finally, as a practical matter, it may be noted that no trade bloc in existence has adopted such liberal membership policies. Entry into existing trade blocs is a slow and carefully negotiated process. As Panagariya (2000) notes "The Canada-U.S. Free Trade Agreement was concluded almost a decade ago and, taking into account NAFTA, its membership has grown to only three so far."

${ }^{16}$ The impact of multilateralism on regionalism has also been studied in the literature. Ethier (1998) and Freund (2000) both view the increased interest in preferential agreements in recent decades as a consequence of successful trade liberalization at the multilateral level. Specifically, Freund (2000) argues that when multilateral tariffs are low, the dangers from trade diversion are small but the benefits from trade creation remain. This increases the likelihood of self-sustaining preferential agreements.

17 In addition to the papers described above, important contributions to this literature include Aghion, Antras and Helpman (2007), Bagwell and Staiger (1997a, 1997b), Cadot, DeMelo and Olarreaga (1999), McLaren (2000) and Saggi (2006).

${ }^{18}$ See also Bohara, Gawande and Sanguinetti (2004) who find links between trade diversion and declining external tariffs in MERCOSUR.
} 
Differently, Limao (2006) considered the question of whether liberalization undertaken by the US in the Uruguay round was related to preferential liberalization prior to the Uruguay round. More specifically, he examines MFN tariff cuts in the Uruguay round for a cross section of products (at HS 8 level of disaggregation) and asks if these cuts were lower on products with a regional preference in place or if the opposite was true. In contrast with Estevadeordal at al. (2008), his findings support the argument that trade preferences may indeed impede multilateral progress; MFN tariff cuts were smaller in products that were subject to trade preferences. Karacaovali and Limao (2008) have repeated this exercise for the EU and found similar results.

Tovar (2010) used data disaggregated at the HS 6 level to examine the same question in the context of the formation of the free trade agreement signed between Costa Rica the Dominican Republic, El Salvador, Guatemala, Honduras, Nicaragua and the United States in 2004 (CAFTA-DR). Focusing on the four focus on the four Central American countries for which the agreement has been in force since 2006: El Salvador, Guatemala, Honduras and Nicaragua, she found that MFN tariffs were raised (or lowered by less) in products with larger reductions in preferential tariffs.

Thus, the examination of MFN tariff liberalization and tariff preferences does not yield an unambiguous answer with regard to the question of whether PTAs impede progress towards multilateral tariff liberalization. We turn our attention next to non-tariff barriers.

\section{3 Non-Tariff Barriers}

Bhagwati (1993) and Bhagwati and Panagariya (1996) have argued that an additional worry with respect to PTA members is that they may resort to the use of the more aggressive use of various forms of administered protection against nonmember countries, as administered protection is more elastic and manipulable by 
domestic players. Thus, while a PTA's structure, in the first instance, might not be trade diversionary, the endogenous trade policy choices made under the PTA may nevertheless yield a diversionary outcome.

In an innovative recent study, Prusa (2011), has evaluated this possibility empirically by examining the use of trade remedy actions (specifically, antidumping duties) by PTA members. The study covers worldwide antidumping activity since 1980 and includes nearly 5000 antidumping cases initiated by WTO members belonging to at least one PTA. The study proceeds in two steps. First, Prusa examines the number of antidumping disputes initiated by PTA members against other PTA members ("intra-PTA filings") is calculated for each importing country, with the goal of comparing trends in intra-PTA filings before and after the formation of the PTA. In a second step, in order to control for global trends in antidumping filing activity, trends in intra-PTA filings are compared with trends in filings by PTA members against non-member countries. The results are striking. In the pre-PTA period, 58 percent of the filings are against non-PTA countries and 42 percent were against PTA members. By contrast, in the post PTA period, 90 percent of the cases were against non-PTA countries while only 10 percent were against PTA members. As Prusa notes, these results "clearly raise the specter of protection diversion and more subtle forms of trade diversion" and that even if "tariff preferences are small and might result in only small amounts of trade diversion", it appears that "other provisions of a PTA might be a greater source of discrimination".

\section{4 Intra-PTA and Extra-PTA trade volumes}

The steady increase in the number of preferential agreements in recent years raises the question of how relevant extra-PTA trade still is for member countries. Have countries already organized themselves into preferential blocs to an extent that most of their trade is with each other and further multilateral liberalization is insignificant? 
Table III lists intra-PTA and extra-PTA trade flows for the year 2008 for a number of prominent trade agreements. The EU has the largest intra-PTA shares with export and import shares both standing at above 60 percent. For NAFTA, intra -PTA exports take up about 50 percent of their overall exports, while intra-PTA imports amount a smaller fraction (33 percent) of their overall imports. Next, we have ASEAN. However, despite the heavy emphasis that Intra-ASEAN trade has received in the literature on PTAs, especially with reference to the large volumes of "fragmented" trade within ASEAN serving as a possible motivation for deeper integration within ASEAN, it is evident that most ASEAN trade (over 75 percent) takes place with countries in the rest of the world. Extra Union trade is greater than 80 percent for nearly all the remaining PTAs and indeed greater than 90 percent for majority of them.

Thus, despite the rapid expansion of preferences in trade, intra-PTA trade shares (and thus extra-PTA shares as well) are relatively small for most PTAs. This suggests that multilateral initiatives involving trade with the rest of the world remain relevant to most member countries of the WTO.

\section{PTAs and Deep Integration?}

Recently, it has begun to be argued that the motivation for PTAs may have little to do with the lowering of trade barriers, as such, and that PTAs should be understood instead as vehicles for undertaking "deeper" forms of integration to achieve institutional harmonization with partner countries. The institutional and policy dimensions along which this harmonization is sought include both provisions that currently fall under the mandate of the WTO and are subject to some level of commitment in WTO agreements (such as the improvement of customs administration and rules concerning public procurement) and those that currently fall outside of mandate of the WTO (such as provisions on investment measures, labor market regulations, innovations policy and human rights). 
To examine the extent of deep integration undertaken in PTAs, we use a data set recently compiled by the WTO (for its 2011 publication of the World Trade Review) which codifies these institutional provisions in over a hundred PTAs notified to the WTO, and additionally indicates which of these provisions are deemed to be legally enforceable. ${ }^{19}$

Table IV provides a list of the policy areas covered in PTAs along with a breakdown of policy areas into those covered by the WTO and those that fall outside of the WTO's mandate. Table IV also indicates the fraction of PTAs (of the 131 PTAs covered by the data set) in which the particular policy area is not included in the text of the PTA and the fraction in which it is included and also deemed to be potentially legally enforceable.

The picture is a mixed one. On the one hand, a number of provisions covered by the WTO are also mentioned in the text of these PTAs and many appear to have legally enforceable status. Thus, over 65 percent of the PTAs in the database include legally enforceable provisions on customs administration, nearly 50 percent of the PTAs include prohibitions on export taxes and slightly over 50 percent include provisions on the administration of antidumping duties. A smaller, but still significant, fraction, include provisions on the liberalization of services and trade related intellectual property rights and investment measures.

On the other hand, provisions that fall outside of the WTO mandates but are covered by PTAs and are also deemed legally enforceable by the text of the PTA are far fewer in number. ${ }^{20}$ Only 4 percent of the PTAs include legally enforceable provisions on

\footnotetext{
${ }^{19}$ As noted by the WTR 2011, in the data set, the codification of policy areas and institutional provisions covered by a PTA and the determination of the legal enforceability of PTA obligations in these domains follows the methodology of Horn, Mavroidis and Sapir (2010). See WTR 2011 for details.

${ }^{20}$ As the WTR 2011 notes, whether or not the actual terminology in a PTA describing a provision "establishes a legally enforceable obligation" is a matter of interpretation. In any event, legal enforceability in theory does not imply easy enforceability in practice, due to a variety of "political factors, resource constraints and other non-legal considerations".
} 
anti-corruption measures, 12 percent include provisions on labor regulation, and 11 percent include provisions on environmental regulations. Regulations on the movement of capital and the protection of intellectual property rights (specifically accession to international treaties not included in the GATS) are more significant at 40 percent and 34 percent respectively, but most of the remaining provisions are simply not referenced in the vast majority of PTAs. This, in itself, permits some skepticism on how much deeper PTAs, on average, have gone beyond the possibilities offered by the WTO. Whether or the not the enforceable provisions will have significant economic effects (for instance, whether provisions on cross-border investment will yield greater flow of investments) remains an open question for future research.

Separately, it has begun to be argued that the fragmentation of global production provides a new basis for countries to achieve preferential integration regionally and at a "deeper" level (see WTR 2011 for a comprehensive discussion). ${ }^{21}$ While this argument is gaining currency in some quarters, it would seem that production fragmentation should provide greater incentives instead for broader multilateral liberalization. After all, the most efficient producers of any given intermediate good need not lie within the jurisdictional boundaries of any specific preferential agreement and the identity and location of the efficient producers of intermediates may be expected to vary faster than any country's ability to sign new preferential agreements. Furthermore, with increased fragmentation the identification of the origin of goods, so that preferences may be suitably granted, is itself a major challenge. ${ }^{22}$ As a practical matter, if PTAs were designed to support fragmented production networks, we might expect to see greater geographic concentration of trade over time as many production networks are regional in nature. As the WTR

\footnotetext{
21 The fragmentation of trade has been well documented in the economics literature For instance, Varian (2007) points out that the popular music player, the Ipod, is made out of well over 400 parts that originate in a number of different countries and are finally assembled in China. See also

22 On this point, see the excellent discussion by Bhagwati (2008, pp 61-70) on why the "who is who" problem of identification of the "true" origin of goods (i.e., as to whether an importable truly originates in a partner country or elsewhere) provides one of the most important arguments against preferences in trade.
} 
2011 notes, however, the share of intra-regional trade in Europe has remained roughly constant at around 73 percent between 1990 and 2009. While Asia's intraregional trade seems to have risen from 42 to 52 percent during the same period, North America's intra-regional trade shares rose from 41 percent in 1990 to 56 percent in 2000 and fell back to 48 percent in 2009.

In any event, it is not obvious that the achievement of "deep integration" at a regional level is a desirable goal from either a regional or multilateral perspective. Common policies may benefit countries with common policy preferences, but may be costly if there are wide differences in the preferences of member countries (as is often the case with provisions involving environmental and labor standards, for instance). In the context of North-South agreements, there is an additional concern that the greater resources and organizational ability of government and sectoral lobbies in the North will shift policy in a direction that is closer to their own interests and away from the interests of the South. Furthermore, the establishment of policies and standards at a regional level may inhibit multilateral liberalization if the multilateral standards vary from regional ones and there are costs to switching standards. It is also conceivable that different regional agreements follow quite different templates making future harmonization difficult, even at the regional level ${ }^{23}$ The possibility of negative spillovers on non-member countries also cannot be ignored. Thus, for instance, prohibition of the use of antidumping duties against partner countries may result in the increased use of antidumping measures against non-members as the work of Prusa (discussed earlier) suggests.

\section{Trade Preferences and the Doha Round}

\footnotetext{
23 The phenomenon of overlapping and criss-crossed preferential agreements, with differing trade rules, especially on the rules of origin that permit goods produced within the agreement to receive duty free treatment, has been famously described by Jagdish Bhagwati as an inefficient "spaghettibowl" of PTAs. As Bhagwati (2008) has also wittily pointed out, evolving these agreements into multilateral free trade requires turning the spaghetti-bowl into a more uniform lasagna, a task that may only be accomplished using flat pasta (identical templates on trade-unrelated issues). Recent experience, for instance in Asia where the US-led Trans Pacific Partnership (TPP) initiative for trade integration that has collided with China's vision for trade in the region, has not been reassuring on this count.
} 
An important issue in the Doha round concerns the extent to which the reduction of multilateral barriers by developing countries erodes the preference margins to those developing countries that already have preferential access to the developed country markets. For instance, under the Everything But Arms (EBA) regulation signed into effect in 2001, the European Union permitted granting duty-free access to imports of all products from 49 LDCs, except arms and ammunitions, without any quantitative restrictions (with the exception of bananas, sugar and rice for a limited period). Multilateral liberalization by the EU would then erode the preferential access of the LDCs to the EU market.

Amiti and Romalis (2007) have studied the question of preference erosion under Doha and argued that lowering tariffs under the multilateral system will lead to a net increase in market access for developing countries. Nevertheless, preference erosion is likely to have important redistributive and thus political economy effects. In the context of the multilateral liberalization proposed in the Doha round, LDCs concerned about the loss of their preferential access, especially in the agricultural sector, could be expected to oppose the round while other developing countries exporters, without prior preferential access to the developed country markets, would likely gain support. Thus, in addition to the fact that developing countries which are net exporters of food have different interests in the round than those that are net importers food, divisions have developed within the set of developing countries based on their prior preferential access to the developed country markets.

Two recent studies confirm these fears. Francois, Hoekman and Manchin (2005) and Limao and Olarreaga (2005) both estimate significant losses to a number of countries in Africa and South Asia due to a full erosion of preferences. Both studies suggest that Bangladesh will suffer the greatest losses from preference erosion (in the range of about 200 million dollars annually). A number of countries are forecast to lose significant fractions of their GDP, for instance, Malawi (8 percent), Lesotho (2.7 percent) and Sao Tome and Principe (1.6 percent). 
To counter the opposition to multilateral liberalization due to preference erosion, a number of solutions, each involving some mechanism to compensate the losers, can be contemplated. One possibility is to simply provide "aid for trade". This would require that countries be given aid money in proportion to their losses. Leaving aside any worries regarding the moral hazard that such policies may generate, such a scheme would require financing in the tune of approximately 500 million to a billion USD annually (see Page, 2005). Even if such aid financing were to be made available, LDCs could worry that these funds would simply be diverted from other intended forms aid. This would require a separate fund to be set up and financed, over and above the aid commitments already under taken by the richer nations.

Another possibility, suggested by Limao and Olarreaga (2005), is for the tariff preferences to be replaced by import subsidies in the same magnitude, so that LDC's whose preferences are eroded, nevertheless have the same export earnings as before. This has theoretical appeal, but runs into the criticism that it replaces one set of distortions within the WTO system with another (even though this transformation will indeed be Pareto improving). As an alternative to compensation for preference erosion, delaying liberalization or gradually liberalizing trade in those sectors with significant preferences has also been suggested. Lawrence and Rosito (2006) have argued for a more complex approach which combines delayed liberalization with a compensation mechanism; they propose that developed countries should be granted a temporary and limited waiver from meeting their liberalization obligations in particular product categories on condition that the additional funds so raised are paid as compensation for preference erosion.

The ideas discussed above provide a range of policy options for the WTO to consider. It is conceivable that any eventual resolution round the Doha will combine different aspects of these proposals. The political experience with liberalization under Doha nonetheless suggests the subtle, yet important, ways in which preferential agreements have impacted the multilateral process and portends 
poorly for future rounds that reach beyond agriculture and aim to unwind the preferences enjoyed on a broader set of goods by a wider range of countries in the existing set of PTAs.

\section{Conclusions}

The question of trade preferences is a complex one. While sharp conclusions are hard to reach, this paper has presented a multilateralist perspective in evaluating this issue in light of recent trends in the international trade system. It has challenged the ideas that PTAs present an efficient alternative to multilateral approaches in achieving genuine liberalization of trade and that PTAs have uniformly enabled the "deep integration" claimed by proponents of preferential trade. It concludes that multilateral initiatives remain desirable and relevant for the member countries of the WTO. 


\section{References}

Aghion, P., Antras, P., and Helpman, E., 2007, "Negotiating Free Trade," Journal of International Economics, 73(1): 1-30

Amiti, M., and Romalis, J., 2007, "Will the Doha Round Lead to Preference Erosion", IMF Staff Papers.

Bagwell, K., and R. Staiger, 1997a, "Multilateral Cooperation during the Formation of Free Trade Areas," International Economic Review.

Bagwell, K., and R. Staiger, 1997b, "Multilateral Cooperation during the Formation of Customs Unions," Journal of International Economics.

Baier, S. L., and Bergstrand, J., 2007, "Do Free Trade Agreements Actually Increase Member Countries Trade," Journal of International Economics, 71: 72-95.

Baldwin, R., 1995, “A Domino Theory of Regionalism," In R. Baldwin, P. Haaparanta, and J. Kiander, eds., Expanding Membership of the European Union, Cambridge University Press

Baldwin, R., and Venables, A., 1995, "Regional Economic Integration," In Gene Grossman and Kenneth Rogoff, eds., Handbook of International Economics, Volume III, Elsevier Science BV

Baldwin, R., 2004, "Stepping stones or building blocs? Regional and Multilateral Integration," Mimeo, Graduate Institute of International Studies, Geneva

Baldwin, R., and Seghezza, E., 2010, "Are Trade Blocs Building or Stumbling Blocs," Journal of Economic Integration, 25(2): 276-297

Bhagwati, J., 1993, "Regionalism and Multilateralism: An Overview," In Jaime deMelo and Arvind Panagariya, eds., New Dimensions in Regional Integration, Cambridge University Press.

Bhagwati, J., 2008, Termites in the Trading System: How Preferential Agreements Undermine Free Trade, Oxford University Press

Bhagwati, J., and Panagariya, A., 1996, "Free Trade Areas or Free Trade?" in The Economics of Preferential Trade Areas, American Enterprise Institute, AEI Press, Washington, DC.

Bhagwati, J., and Panagariya, A. and Krishna. P., 1999, Trading Blocs: Alternative Approaches to Analyzing Preferential Trade Agreements, MIT Press. 
Bohara, A., Gawande, K., and Sanguinetti, P., 2004, "Trade Diversion and Declining Tariffs: Evidence from MERCOSUR," Journal of International Economics, 64:1-27.

Cadot, O., DeMelo J., and Olarreaga, M., 1999, "Regional Integration and Lobbying for Tariffs Against Non-members," International Economic Review.

Chang, W., and Winters, A., 2002, "How Regional Trade Blocs Affect Excluded Countries: The Price Effects of MERCOSUR," The American Economic Review, Vol. 92, pp 889-904.

Clausing, K., 2001, "Trade Creation and Trade Diversion in the Canada-United States Free Trade Agreement," Canadian Journal of Economics, 34: 678-96

Estevadeordal, A., Freund, C., and Ornelas, E., 2008, "Does Regionalism Affect Trade Liberalization towards Non-Members," Quarterly Journal of Economics, 123: 15311575 .

Ethier, W., 1998, “Regionalism in a Multilateral World," Journal of Political Economy

Frankel, J., Stein, E., and Wei, S., 1996, "Trading Blocs: The Natural, The Unnatural and The Super Natural?," Journal of Development Economics, 47(1), pp 61-95.

François, J., Hoekman, B., and Manchin, M. 2005, "Preference Erosion and Multilateral Trade Liberalization," Tinbergen Institute Discussion Paper, 2005-073/2

Freund, C., 2000, "Multilateralism and the Endogenous Formation of PTAs," Journal of International Economics

Grossman, G., and Helpman, E., 1995, "The Politics of Free Trade Agreements," American Economic Review

Grinols, E., 1981, "An Extension of the Kemp-Wan Theorem on the Formation of Customs Unions," Journal of International Economics

Horn, H., Mavroidis, P C., and Sapir, A., 2010, "Beyond the WTO: An Anatomy of EU and US Preferential Trade Agreements," The World Economy, 33 (11): 1565-1588

Joshi, V., 2010a, "Preferential Tariff Formation: The Case of the European Union," Working Paper, Graduate Institute of International and Development Studies, Number 05/2010

Joshi, V., 2010b, "Preferential Tariff Formation in the United States," Working Paper, Graduate Institute of International and Development Studies, Number 06/2010

Karacavaoli, B., and Limao, N., 2008, "The Clash of Liberalizations: Preferential vs 
Multilateral Trade Liberalization in the European Union," Journal of International Economics, 74: 299-327.

Kemp, M., 1964, The Pure Theory of International Trade, Prentice-Hall, N.J.

Kemp, M., and Wan, H., 1976, "An Elementary Proposition Concerning the Formation of Customs Unions," Journal of International Economics

Krishna, P., 1998, "Regionalism and Multilateralism: A Political Economy Approach," Quarterly Journal of Economics.

Krishna, P., 2003, “Are Regional Trading Partners Natural?," Journal of Political Economy.

Krishna, P., 2005, Trade Blocs: Economics and Politics, Cambridge University Press.

Krugman, P., 1991, "The Move To Free Trade Zones," In Federal Reserve Bank of Kansas City, Policy Implications of Trade and Currency Zones, Kansas City: Federal Reserve Bank of Kansas City, 7-41.

Lawrence, Robert, 1997, Regionalism, Multilateralism and Deeper Integration, Washington: Brookings Institution.

Lawrence, R., and Rosito, T., 2006, "A New Compensation Mechanism for Preference Erosion in the Doha Round," Working Paper, Kennedy School of Government, Harvard University, RWP 06-044

Limao N., and Olarreaga, M., 2005, "Trade Preferences to Small Developing Countries and the Welfare Costs of Lost Multilateral Liberalization," World Bank Policy Research Working Paper, WPS3565

Limao N., 2006, "Preferential Trade Agreements as Stumbling Blocs for Multilateral Trade Liberalization: Evidence for the US," American Economic Review, 96: 896-914

Levy, P., 1997, "A Political Economic Analysis of Free Trade Arrangements," American Economic Review

Magee, C., 2008, "New Measures of Trade Creation and Trade Diversion," Journal of International Economics, 75:340-362

McLaren, J., 1999, “A Theory of Insidious Regionalism," American Economic Review

Mundell, R., 1964, "Tariff Preferences and the Terms of Trade," Manchester School of Economic Studies, 1-13. 
Ohyama, M., 1972, "Trade and Welfare in General Equilibrium," Keio Economic Studies, 9, 37-73.

Ornelas, E., 2005a, "Trade Creating Free Trade Areas and the Undermining of Multilateralism", European Economic Review, 49: 1717-1735

Ornelas, E., 2005b, "Rent Destruction and the Political Viability of Free Trade Agreements" Quarterly Journal of Economics, 120: 1475-1506

Page, S., 2005, "A Preference Erosion Compensation Fund: A New Proposal to Protect Countries from the Negative Effects of Trade Liberalization," Overseas Development Institute, Opinions 35, January 2005

Panagariya, A., 1997, "Preferential Trading and the Myth of Natural Trading Partners," Japan and the World Economy

Panagariya, A., 2000, "Preferential Trade Liberalization: The Traditional Theory and New Developments," Journal of Economic Literature

Panagariya, A. and Krishna, P., 2002, "On the Existence of Necessarily Welfare Improving Free Trade Areas," Journal of International Economics

Prusa, T., 2011, "Trade Remedy Provisions," in Chaffour and Maur editors, Preferential Trade Agreement Policies for Development, World Bank, Washington DC

Romalis, J., 2007, NAFTA's and CUSFTA's effects on International Trade, Review of Economics and Statistics, 89(3), pp 416-435.

Saggi, K., 2006, "Preferential Trade Agreements and Multilateral Tariff Cooperation", International Economic Review, 47:29-58

Saggi K., and Yildiz H. M. 2008, "Bilateral Trade Agreements and the Feasibility of Multilateral free trade," Working Paper, Southern Methodist University

Saggi K., and Yildiz H. M., 2009, "Bilateralism, Pure Multilateralism, and the quest for global free trade," Working Paper, Southern Methodist University

Tovar, P., 2009, "Preferential Trade Agreements and Unilateral Liberalization: Evidence from CAFTA", Mimeo, Brandeis University

Trefler, D., 2004, "The Long and the Short of the Canada-United States Free Trade Agreement," American Economic Review, 94:870-895

Vanek, J., 1965, General Equilibrium of International Discrimination, Harvard University Press. 
Varian, H., 2007, "An Ipod Has Global Value, Ask the (Many) Countries That Make it", New York Times, June 28.

Viner, J., 1950, The Customs Unions Issue, Carnegie Endowment for International Peace, New York.

World Trade Report, 2011, "The WTO and Preferential Trade Agreements," WTO, Geneva

Yeats, A., 1998. "Does MERCOSUR's Trade Performance Raise Concerns about the Effects of Regional Trade Arrangements?" The World Bank Economic Review, Vol. 12, (1), pp 1-28.

Yi, S., 1996, "Endogenous Formation of Customs Unions under Imperfect Competition: Open Regionalism is Good," Journal of International Economics. 
Table I: Trade Under Preferences (2008)

\begin{tabular}{|c|c|c|c|c|c|c|c|c|}
\hline \multirow[t]{2}{*}{ Regime } & \multicolumn{3}{|c|}{ Preferential Trade } & \multicolumn{3}{|c|}{ Non-Preferential Trade } & \multirow{2}{*}{ MFN=0 } & \multirow{2}{*}{$\begin{array}{c}\text { Trade } \\
\text { Billions (USD) }\end{array}$} \\
\hline & Total & $\mathrm{PM}>10 \%$ & $\mathrm{PM}<10 \%$ & Total & MFN $>10 \%$ & MFN $<10 \%$ & & \\
\hline MFN & 0 & 0 & 0 & 44.8 & 4.9 & 40 & 53.9 & 4874 \\
\hline EU-intra & 63.7 & 9.4 & 54.3 & 0 & 0 & 0 & 34.4 & 3807 \\
\hline Reciprocal Regimes & 43.7 & 5.8 & 37.9 & 7.6 & 1 & 6.6 & 47 & 2803 \\
\hline NAFTA & 60.9 & 6.3 & 54.7 & 0.1 & 0 & 0 & 38.2 & 912 \\
\hline EU - Switzerland & 56.9 & 3.9 & 53 & 1.3 & 0.5 & 0.8 & 41 & 261 \\
\hline ASEAN* & 20.1 & 4 & 16 & 3.6 & 0.3 & 3.3 & 72.9 & 141 \\
\hline EU-Turkey & 78.4 & 15.2 & 63.2 & 0.9 & 0.5 & 0.4 & 20 & 141 \\
\hline EU-Mexico & 51.2 & 13.5 & 37.7 & 0.9 & 0.6 & 0.3 & 43.2 & 58 \\
\hline Non-Reciprocal Regimes & 17.6 & 1 & 16.6 & 26.3 & 5.4 & 21 & 55.6 & 2067 \\
\hline EU-GSP & 13.3 & 0.1 & 13.2 & 23 & 5.7 & 17.3 & 63.4 & 1012 \\
\hline US-GSP & 8.3 & 0.2 & 8.1 & 62.4 & 5.6 & 56.8 & 28.8 & 258 \\
\hline US-AGOA & 90.1 & 1.5 & 88.6 & 0.1 & 0 & 0 & 9.9 & 84 \\
\hline
\end{tabular}

Source; World Trade Review 2011 
Table II: Regional Orientation of Trade and Comparative Advantage - MERCOSUR

\begin{tabular}{|c|c|c|c|c|c|c|}
\hline Product & $\begin{array}{c}\text { Exports (Thousands USD) } \\
1998\end{array}$ & $\begin{array}{c}\text { Exports (Thousands USD) } \\
1994\end{array}$ & $\begin{array}{c}\text { Regional Orientation } \\
1988\end{array}$ & $\begin{array}{c}\text { Regional Orientation } \\
1994\end{array}$ & $\Delta$ Regional Orientation & Comparative Advantage \\
\hline Nonalcoholic beverages & 349 & 26238 & 2.35 & 48.47 & 46.12 & 0.05 \\
\hline Lead & 642 & 219 & 3.03 & 25.42 & 22.39 & 0 \\
\hline Prepared dairy & 23495 & 204019 & 4.31 & 22.49 & 18.17 & 0.13 \\
\hline Nonwheat meal or Flour & 4 & 954 & 0.05 & 17.26 & 17.21 & 0.04 \\
\hline Perfumes and Cosmetics & 4766 & 86282 & 5.22 & 13.37 & 8.16 & 0.14 \\
\hline Wheat meal or Flour & 65 & 35051 & 0.22 & 5.67 & 5.44 & 1.08 \\
\hline Cork manufactures & 18 & 721 & 1.18 & 6.3 & 5.13 & 0.05 \\
\hline Preserved vegetables & 23404 & 48745 & 17.66 & 22.61 & 4.95 & 0.13 \\
\hline Articles of Paper & 15763 & 72249 & 2.16 & 7.1 & 4.93 & 0.2 \\
\hline Nonmotor road vehicles & 3118 & 35854 & 2.23 & 6.88 & 4.65 & 0.13 \\
\hline Alcoholic beverages & 4137 & 81671 & 1.87 & 6.48 & 4.61 & 0.19 \\
\hline Agricultural machinery & 39608 & 121294 & 2.08 & 5.88 & 3.81 & 0.45 \\
\hline Domestic electrical machiner & 12568 & 97322 & 2.19 & 5.94 & 3.76 & 0.23 \\
\hline Road motor vehicles & 206996 & 2112750 & 1.25 & 4.42 & 3.17 & 0.45 \\
\hline Materials of rubber & 3636 & 30780 & 3.13 & 6.26 & 3.13 & 0.32 \\
\hline Glassware & 45017 & 2.21 & 5.09 & 2.88 & 0.38 & \\
\hline Synthetic fibers & 13381 & 21170 & 6.28 & 9.14 & 2.87 & 0.11 \\
\hline Rice (glazed) & 22583 & 148079 & 9.28 & 11.65 & 2.37 & 1.03 \\
\hline Lace and Ribbons & 1386 & 13157 & 3.56 & 5.86 & 2.29 & 0.22 \\
\hline Food preparations & 7727 & 45412 & 2.1 & 4.35 & 2.25 & 0.28 \\
\hline
\end{tabular}

Source: Yeats (1998) 
Table III: Intra-PTA and Extra-PTA Trade (2008)

\begin{tabular}{|c|c|c|c|c|c|c|}
\hline \multirow[t]{2}{*}{ Preferential Trade Agreement } & \multicolumn{2}{|c|}{ World (Billions USD) } & \multicolumn{2}{|c|}{ Intra-PTA Share } & \multicolumn{2}{|c|}{ Extra-PTA Share } \\
\hline & Export & Import & Export & Import & Export & Import \\
\hline ANDEAN Community & 94 & 93 & 7 & 8 & 93 & 92 \\
\hline ASEAN Free Trade Area (AFTA) & 966 & 929 & 25 & 24 & 75 & 76 \\
\hline Asia Pacific Trade Agreement (APTA) & 2043 & 1897 & 11 & 19 & 89 & 81 \\
\hline Caribbean Community and Common Market (CARICOM) & 26 & 29 & 16 & 12 & 84 & 88 \\
\hline Central American Common Market (CACM) & 25 & 44 & 24 & 11 & 76 & 89 \\
\hline Common Market for Eastern and Southern Africa (COMESA) & 57 & 115 & 10 & 5 & 90 & 95 \\
\hline Commonwealth of Independent States (CIS) & 693 & 456 & 18 & 27 & 82 & 73 \\
\hline Economic Community of West African States (ECOWAS) & 71 & 58 & 8 & 9 & 92 & 91 \\
\hline European Free Trade Association (EFTA) & 374 & 279 & 1 & 1 & 99 & 99 \\
\hline European Union (27) & 5806 & 6083 & 67 & 60 & 33 & 40 \\
\hline Global System of Trade Preferences (GSTP) & 1437 & 1486 & 19 & 22 & 81 & 78 \\
\hline Gulf Cooperation Council & 704 & 366 & 2 & 7 & 98 & 93 \\
\hline Latin American Integration Association & 814 & 760 & 16 & 18 & 84 & 82 \\
\hline North American Free Trade Agreement (NAFTA) & 2047 & 2882 & 49 & 33 & 51 & 67 \\
\hline Pan-Arab Free Trade Area (PAFTA) & 892 & 607 & 6 & 11 & 94 & 89 \\
\hline South Asian Free Trade Agreement (SAFTA) & 211 & 374 & 6 & 2 & 94 & 98 \\
\hline Southern Common Market (MERCOSUR) & 278 & 249 & 17 & 18 & 83 & 82 \\
\hline
\end{tabular}

Source: World Trade Review 2011 


\begin{tabular}{|c|c|c|c|}
\hline \multicolumn{2}{|r|}{ Description of Provisions } & $\begin{array}{l}\text { Provision Not Mentioned } \\
\text { Fraction of PTAs }\end{array}$ & $\begin{array}{c}\begin{array}{c}\text { Provision Mentioned and } \\
\text { Legally Enforceable }\end{array} \\
\text { Fraction of PTAs }\end{array}$ \\
\hline \multicolumn{4}{|c|}{ 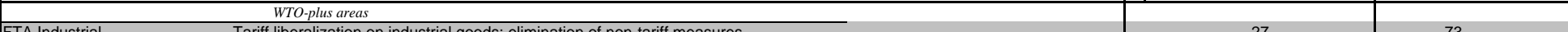 } \\
\hline FTA Industrial & Tariff liberalization on industrial goods; elimination of non-tariff measures & 27 & 73 \\
\hline FTA Agriculture & Tariff liberalization on agriculture goods; elimination of non-tariff measures & 27 & 73 \\
\hline Customs & Provision of information; publication on the Internet of new laws and regulations; training & 35 & 65 \\
\hline Export Taxes & Elimination of export taxes & 52 & 48 \\
\hline SPS & Affirmation of rights and obligations under the WTO Agreement on SPS; harmonization of SPS measures & 69 & 21 \\
\hline TBT & Affirmation of rights and obligations under WTO Agreement on TBT; harmonization of regulations; & 67 & 30 \\
\hline STE & Establishment of an independent competition authority; nondiscrimination regarding production and marketing condition; & 64 & 34 \\
\hline$A D$ & Retention of Antidumping rights and obligations under the WTO Agreement (Art. VI GATT). & 40 & 53 \\
\hline CVM & Retention of Countervailing measures rights and obligations under the WTO Agreement (Art VI GATT) & 49 & 44 \\
\hline State Aid & Assessment of anticompetitive behaviour; annual reporting on the value and distribution of state aid given & 57 & 39 \\
\hline Public Procurement & Progressive liberalisation; national treatment and/or non-discrimination principle; specification of public procurement regime & 70 & 27 \\
\hline TRIMs & Provisions concerning requirements for local content and export performance of FDI & 69 & 31 \\
\hline GATS & Liberalisation of trade in services & 61 & 39 \\
\hline TRIPS & Harmonisation of standards; enforcement; national treatment, most-favoured nation treatment & 56 & 43 \\
\hline \multicolumn{4}{|c|}{ WTO-X areas } \\
\hline Anti-Corruption & Criminal offence measures in matters affecting international trade and investment & 96 & 4 \\
\hline Competition Policy & Harmonisation of competition laws; establishment of an independent competition authority & 52 & 30 \\
\hline Environmental Laws & Development of environmental standards; enforcement of national environmental laws & 85 & 11 \\
\hline IPR & Accession to international treaties not referenced in the TRIPs Agreement & 62 & 34 \\
\hline Investment & Legal frameworks; Harmonisation; National treatment; mechanism for the settlement of disputes & 69 & 30 \\
\hline Labour Market Regulation & Regulation of the national labour market; affirmation of ILO commitments; enforcement & 85 & 12 \\
\hline Movement of Capital & Liberalisation of capital movement; prohibition of new restrictions & 60 & 40 \\
\hline Consumer Protection & Harmonisation of consumer protection laws; exchange of information and experts; training & 95 & 4 \\
\hline Data Protection & Exchange of information and experts; joint projects & 95 & 3 \\
\hline Agriculture & Technical assistance to conduct modernisation projects; exchange of information & 93 & 5 \\
\hline Approximation of Legislation & Application of EC legislation in national legislation & 95 & 5 \\
\hline Audio Visual & Promotion of the industry; encouragement of co-production & 100 & 0 \\
\hline Civil Protection & Implementation of harmonised rules & 100 & 0 \\
\hline Innovation Policies & Participation in framework programmes; promotion of technology transfers & 99 & 1 \\
\hline Cultural Cooperation & Promotion of joint initiatives and local culture & 98 & 1 \\
\hline Economic Policy Dialogue & Exchange of ideas and opinions; joint studies & 98 & 1 \\
\hline Education and Training & Measures to improve the general level of education & 94 & 3 \\
\hline Energy & Exchange of information; technology transfer; joint studies & 94 & 5 \\
\hline Financial Assistance & Set of rules guiding the granting and administration of financial assistance & 95 & 5 \\
\hline Health & Monitoring of diseases; development of health information systems; exchange of information & 99 & 0 \\
\hline Human Rights & Respect for human rights & 100 & 0 \\
\hline IIllegal Immigration & Conclusion of re-admission agreements; prevention and control of illegal immigration & 98 & 2 \\
\hline IIlicit Drugs & Treatment and rehabilitation of drug addicts; joint projects on prevention of consumption; & 100 & 0 \\
\hline Industrial Cooperation & Assistance in conducting modernisation projects; facilitation and access to credit to finance & 96 & 3 \\
\hline Information Society & Exchange of information; dissemination of new technologies; training & 96 & 3 \\
\hline Mining & Exchange of information and experience; development of joint initiatives & 98 & 1 \\
\hline Money Laundering & Harmonisation of standards; technical and administrative assistance & 100 & 0 \\
\hline Nuclear Safety & Development of laws and regulations; supervision of the transportation of radioactive materials & 100 & 0 \\
\hline Political Dialogue & Convergence of the parties' positions on international issues & 100 & 0 \\
\hline Public Administration & Technical assistance; exchange of information; joint projects; Training & 100 & 0 \\
\hline Regional Cooperation & Promotion of regional cooperation; technical assistance programmes & 97 & 2 \\
\hline Research and Technology & Joint research projects; exchange of researchers; development of public-private partnership & 93 & 5 \\
\hline SME & Technical assistance; facilitation of the access to finance & 95 & 2 \\
\hline Social Matters & Coordination of social security systems; non-discrimination regarding working conditions & 91 & 8 \\
\hline Statistics & Harmonisation and/or development of statistical methods; training & 98 & 2 \\
\hline Taxation & Assistance in conducting fiscal system reforms & 98 & 2 \\
\hline Terrorism & Exchange of information and experience; joint research and studies & 100 & 0 \\
\hline Visa and Asylum & Exchange of information; drafting legislation; training & 85 & 14 \\
\hline
\end{tabular}

Source: World Trade Review 2011 


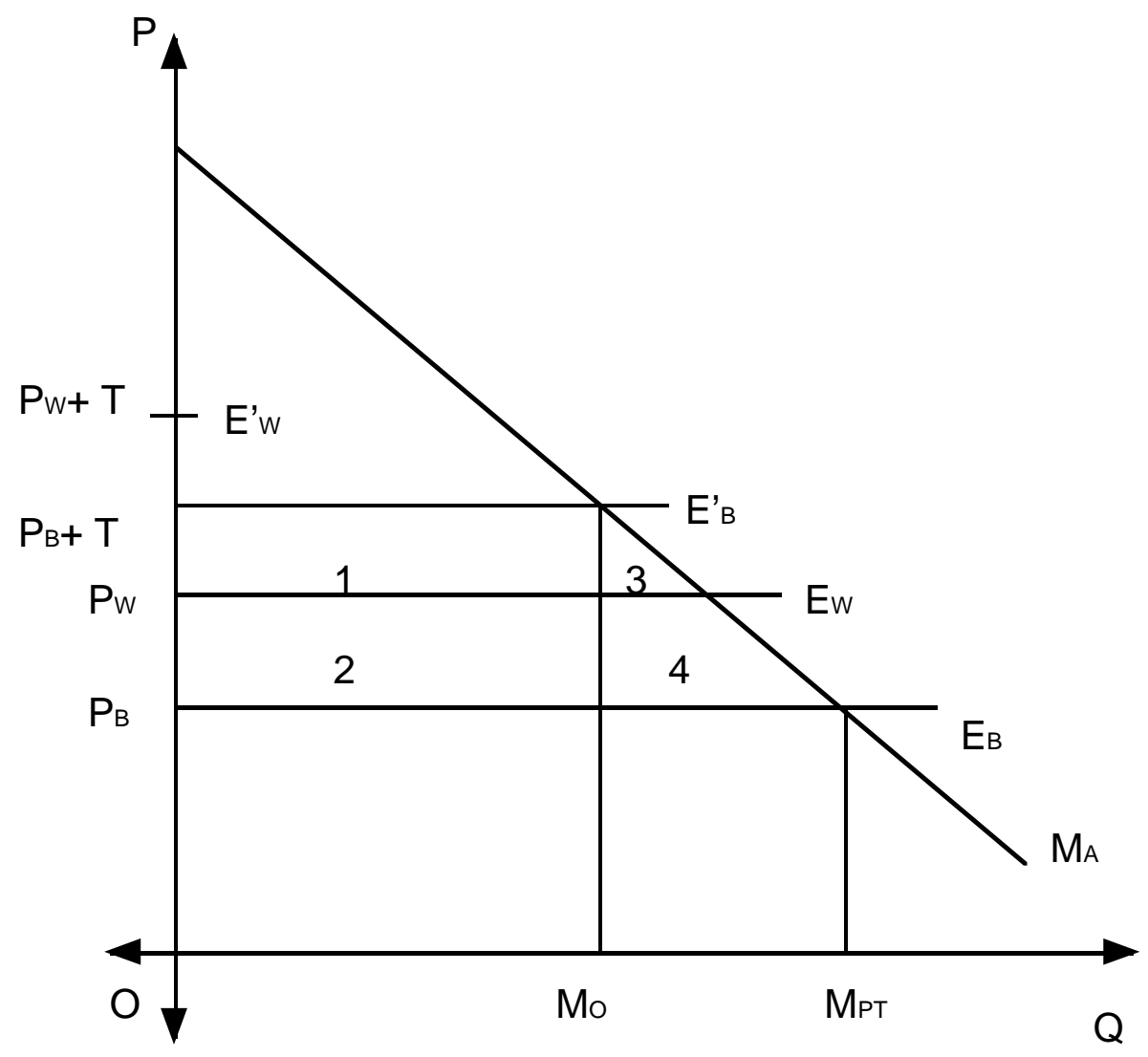

Figure I

Trade Creating Tariff Preferences

Change in Welfare $=(3+4)$ 


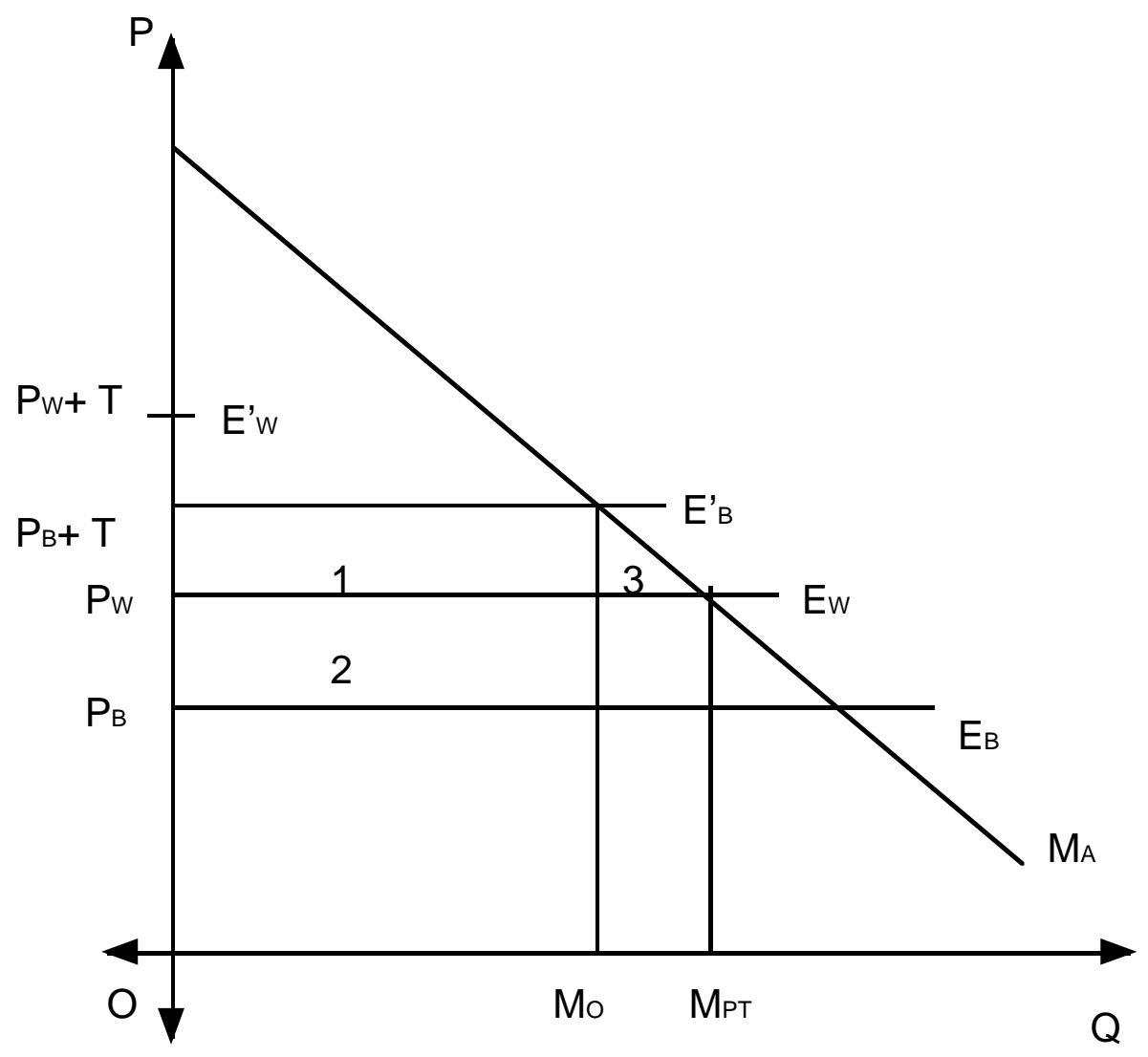

Figure II

Trade Diverting Tariff Preferences:

Change in Welfare $=(3-2)$ 


\section{Figure III: External terms of Trade Effects - MERCOSUR}
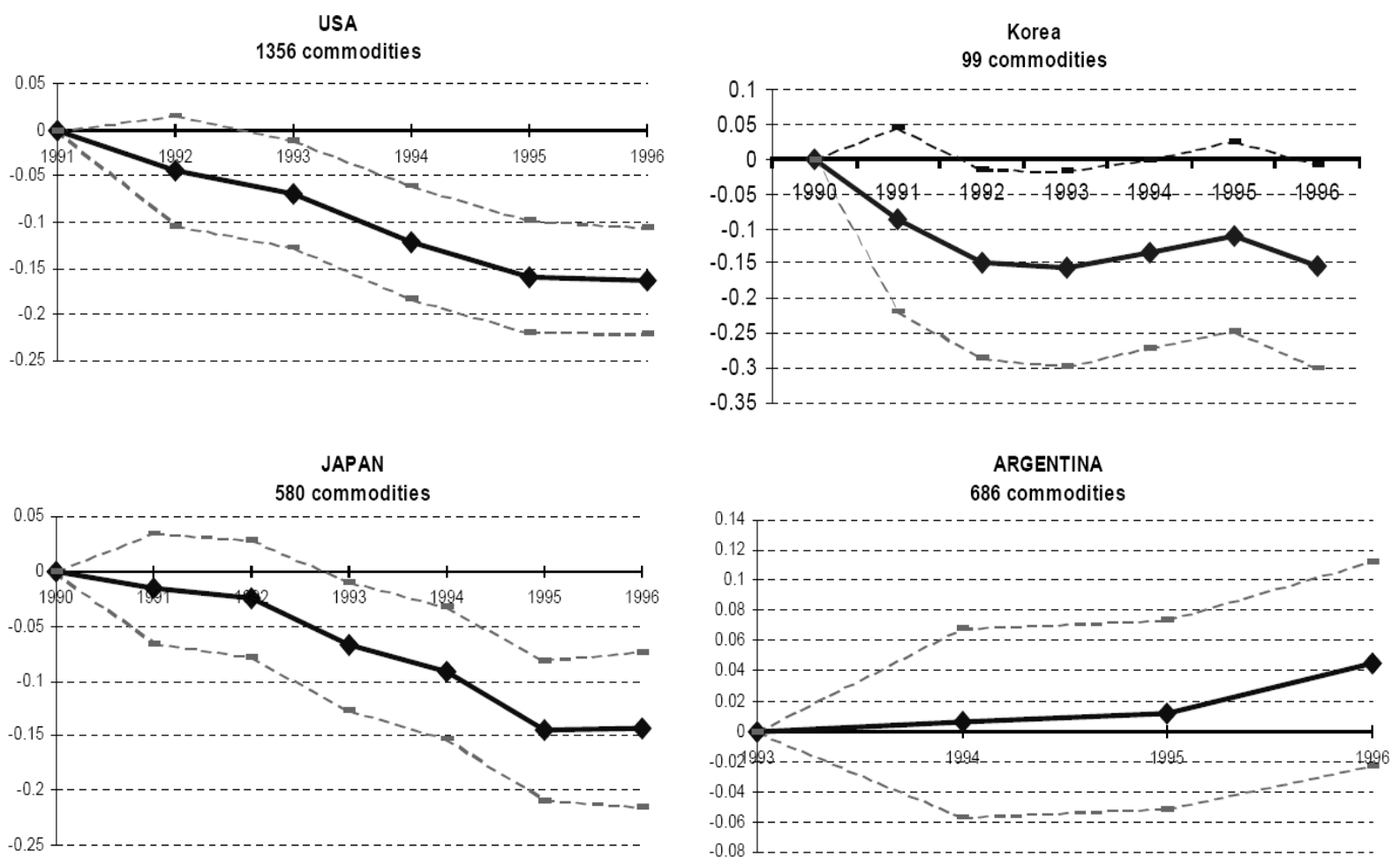

Source: Chang and Winters (2002) 